\title{
Membrane Removal of Emerging Contaminants from Water: Which Kind of Membranes Should We Use?
}

\author{
Magda Kárászová ${ }^{1}$, Mahdi Bourassi ${ }^{1,2}$ and Jana Gaálová ${ }^{1, *}$ \\ 1 Institute of Chemical Process Fundamentals of the CAS, v.v.i., Rozvojova 135, 16500 Prague, Czech Republic; \\ karaszova@icpf.cas.cz (M.K.); bourassi@icpf.cas.cz (M.B.) \\ 2 Faculty of Science, Charles University, Institute for Environmental Studies, Benátská 2, \\ 12801 Prague 2, Czech Republic \\ * Correspondence: gaalova@icpf.cas.cz; Tel.: +420-220-390-255
}

Received: 2 October 2020; Accepted: 20 October 2020; Published: 25 October 2020

check for updates

\begin{abstract}
Membrane technologies are nowadays widely used; especially various types of filtration or reverse osmosis in households, desalination plants, pharmaceutical applications etc. Facing water pollution, they are also applied to eliminate emerging contaminants from water. Incomplete knowledge directs the composition of membranes towards more and more dense materials known for their higher selectivity compared to porous constituents. This paper evaluates advantages and disadvantages of well-known membrane materials that separate on the basis of particle size, usually exposed to a large amount of water, versus dense hydrophobic membranes with target transport of emerging contaminants through a selective barrier. In addition, the authors present several membrane processes employing the second type of membrane.
\end{abstract}

Keywords: dense membranes; emerging contaminants; water quality

\section{Introduction}

Emerging contaminants (ECs) are once again raising the question of water quality [1-8] due to the serious effects of long-term contact, sometimes even at very low concentrations in drinking or surface water. Such amounts have, for many years, been either neglected, difficult to measure or unmeasurable by available analytical methods [9-11]. Therefore, there is naturally a time lag between the identification of a particular contaminant and its appearance in any form of directive regulating water quality. The European directive from 1998 related to drinking water quality, 98/83/ES, covers no endocrine-disrupting compounds, pharmaceuticals or personal-care products, but the new directive from 2017, 2017/0332 (COD) includes perfluorinated compounds and three endocrine-disrupting compounds (beta estradiol, nonylphenol and bisphenol A). The directives for surface water 2008/105/ES, dealing with environmental quality standards for 45 chemical substances, contain 14 endocrine-disrupting compounds according to the European database of endocrine-disrupting compounds (commission document SEC (2007) 1635), still does not include pharmaceuticals or personal-care products. Another approach to the correction of the situation is presented in the watch-list of monitored chemical substances in the European Commission implementing decision 2018/840 (repealing Commission implementing decision (EU) 2015/495). The list contains 18 contaminants of emerging concern: hormones, macrolide antibiotics and neonicotinoid insecticides included. The substances on the list are subject to monitoring in European countries and could potentially be included in their water directives. Although the process of assessing the contaminants and their inclusion in the legislation is a rather complicated and slow one, it is already obvious that technology for removing these compounds from water will soon be absolutely necessary. Emerging contaminants (ECs), however, refer to a group of substances with very different properties, 
from their molecular weights to their saturated vapor pressures. To illustrate the diversity of the group, Table 1 shows several physical and chemical properties of selected ECs.

Table 1. Diversity of environmental contaminants (ECs)—physical and chemical properties of selected compounds from the group (e.g., M-molar mass; Log. Kow-octanol/water partition coefficient; $\mathrm{MP}$-melting point; $\mathrm{p}$ - pressure; w solub—water solubility).

\begin{tabular}{|c|c|c|c|c|c|c|}
\hline Category & Name & $\underset{(\mathrm{g} / \mathrm{mol})}{\mathrm{M}}$ & $\begin{array}{l}\text { Log } \\
\text { Kow }\end{array}$ & $\begin{array}{l}\mathrm{MP} \\
\left({ }^{\circ} \mathrm{C}\right)\end{array}$ & $\begin{array}{c}\text { p sat at } 25^{\circ} \mathrm{C} \\
(\mathrm{Pa})\end{array}$ & $\begin{array}{c}\text { w solub } \\
(\mathrm{mg} / \mathrm{L})\end{array}$ \\
\hline Hormones & 117-b-estradiol & 272.4 & 4.01 & 176 & $8.50 \times 10^{-7}$ & 3.6 \\
\hline Hormones & Gestodene & 270.4 & 3.13 & 255 & & 30 \\
\hline Antibiotics & Sulfamethoxazole & 253.3 & 0.89 & 167 & $9.23 \times 10^{-6}$ & 610 \\
\hline Antibiotics & Sulfapyridine & 250.3 & 0.35 & 192 & & 268 \\
\hline Lipid regulators & Clofibrate & 242.7 & 3.02 & $<25$ & & insoluble \\
\hline Lipid regulators & Gemifibrozil & 250.3 & 4.77 & 62 & $4.10 \times 10^{-3}$ & 11 \\
\hline NAIDs & Ibuprofen & 206.3 & 3.97 & 76 & $6.30 \times 10^{-3}$ & 21 \\
\hline NAIDs & Aspirin & 180.2 & 1.19 & 135 & $3.60 \times 10^{-3}$ & 4600 \\
\hline NAIDs & Diclofenac & 296.1 & 4.51 & 285 & $8.82 \times 10^{-5}$ & 2.37 \\
\hline NAIDs & Paracetamol & 151.2 & 0.33 & 170 & $8.40 \times 10^{-3}$ & 14,000 \\
\hline Betablockers & Pindolol & 248.3 & 1.75 & 170 & & 7880 \\
\hline Betablockers & Propranolol & 259.3 & 3.48 & 96 & & 61 \\
\hline Anti-depressants & Amitriptiline & 277.4 & 4.81 & 196 & $4.80 \times 10^{-5}$ & 9.71 \\
\hline Anti-depressants & Meprobamate & 218.3 & 0.93 & 105 & $4.00 \times 10^{-1}$ & 4700 \\
\hline Anti-convulsants & Carbamazepine & 236.3 & 13.9 & 190 & $2.40 \times 10^{-5}$ & 17.7 \\
\hline Anti-convulsants & Cabapentine & 171.2 & -1.10 & 165 & $4.00 \times 10^{-8}$ & 4490 \\
\hline Preservatives & 2-phenoxyethanol & 138.2 & 1.16 & 14 & $1.30 \times 10^{0}$ & 24,000 \\
\hline Preservatives & Methylparaben & 151.2 & 1.96 & 131 & $3.20 \times 10^{-2}$ & 2500 \\
\hline Preservatives & Ethyl-4-hydroxy benzoate & 166.2 & 2.47 & 117 & $1.20 \times 10^{-2}$ & 885 \\
\hline Disinfectants & 2-phenylphenol & 170.2 & 3.09 & 60 & $2.70 \times 10^{-1}$ & 700 \\
\hline Disinfectants & Chloroprene & 88.5 & 2.2 & -130 & $2.51 \times 10^{4}$ & 260 \\
\hline Disinfectants & Bromoprene & 133 & & -126 & $7.35 \times 10^{3}$ & \\
\hline Plasticizers & Diethyl phthalate & 222.2 & 2.47 & -4 & $2.60 \times 10^{-1}$ & 1080 \\
\hline Plasticizers & Di(2-ethylhexyl) phthalate & 390.6 & 7.6 & -55 & $1.80 \times 10^{-5}$ & 0.27 \\
\hline Plasticizers & Benzylbutyl phthalate & 312.3 & 4.73 & -35 & $1.10 \times 10^{-3}$ & 2.69 \\
\hline Plasticizers & Bis(2-ethylhexyl) adipate & 370.6 & 8.1 & -70 & $1.13 \times 10^{-4}$ & 0.1 \\
\hline Plasticizers & Dibutylphthalate & 278.3 & 4.5 & -35 & $2.70 \times 10^{-3}$ & 11.2 \\
\hline Plasticizers & 1,2-dibromo-3-chloropropane & 236.6 & 2.96 & 6 & $1.07 \times 10^{2}$ & 1.23 \\
\hline Pesticides & Glyphosate & 168.1 & -3.20 & 189 & $1.50 \times 10^{-5}$ & 1200 \\
\hline
\end{tabular}

Notwithstanding the fact of dealing with sometimes hard to measure soluble amounts in water, Table 1 clearly illustrates the main issue of removal of ECs from water, their diversity. That is why no universal method for their removal from water exists. Even narrowing the area of interest to, for example, pharmaceuticals, does not solve the problem because, for example, ibuprofen has dramatically different water solubility than paracetamol but they are both in the same group, called NSAIDs (nonsteroidal anti-inflammatory drugs). Different interesting reviews dealing with methods for removal of ECs [12-19] have common the conclusions: "The method was found to be quite effective, but..." The only thing common to ECs is the fact that they consist of carbon, hydrogen and oxygen. Yet, because wastewater treatment plants are not able to completely remove ECs [20-24], a strong effort is being made to find the right technologies.

Yang et al. [15] presented the following prospective methods for removal of ECs from wastewaters:

- Membrane filtration; specially NF and RO due to very small pores $(<2 \mathrm{~nm})$.

- Granular and powdered activated carbon adsorption for rapid filters and seasonal uses.

- Advanced oxidation processes recommended as extra treatments especially for drinking water quality improvement.

Wang et al. [13] mentioned also: 
- Graphene and graphene oxide adsorption due to their high and functionalized surface areas.

- Adsorption on carbon nanotubes with high adsorption performance and physicochemical properties (despite high costs).

- Biological degradation, the most used technique, requires space and time but is energy efficient.

Some alternative methods may be added:

- Constructed wetlands gathering a combination of natural processes: sedimentation, microbial hydrolysis and photolysis degradation [25-27].

- Metal organic framework adsorption (relatively new technology) [28].

The number of sorbents used is still increasing [14,29-34]. Especially carbon-based materials [31,33,34] are mentioned, but we can find also carbon nanotubes [12] and metal organic frameworks (MOFs) [28,35]. The hottest trend seems to be the use of plant-based coagulants [36], especially proteins of Moringa olifeira seeds [37]. New methods are also the subject of several recently accepted patents [38-43].

All of these methods have advantages and disadvantages. For example, advanced oxidation processes (AOPs), which are generally considered to be the most effective and universal, employ oxygen or free radicals to initiate the oxidation of undesired compounds $[44,45]$. The reaction should yield a less dangerous product or $\mathrm{CO}_{2}$ and $\mathrm{H}_{2} \mathrm{O}$ (total mineralization). AOPs and advanced catalytic oxidations are a very complex group of processes including ozonation, Fenton and foto-Fenton reaction, sonolysis, catalytic wet air oxidation processes, combined AOPs etc. [17,46-52]. AOPs show good ability to remove different types of emerging contaminants from water, but the problem is the possible toxicity of the byproducts of the reactions, which may be more toxic or biologically active than the original compounds. There may be a great difference between the results obtained with synthetic wastewater samples and real wastewater samples because real wastewater is a complex system and identification of the oxidation by-products may be difficult. The result of the application of AOPs for removal of ECs is influenced by the $\mathrm{pH}$ of the solution, the matrix, the presence of natural organic matter in the matrix and the dose irradiation. Carbon nanotubes (CNTs) [12] have a high adsorption potential and are better defined than activated carbon, but their adsorption is influenced by the chemistry of the solution, the surface chemistry of the CNTs, the type of packing etc. Besides that, there is a problem of the high price and possible toxicity of CNTs; to substitute one toxic component in the wastewater with another one is undesirable.

Membrane technology suitable for ECs is problematic because of the diverse physicochemical properties of materials and the wide range of parameters to combine for separation enhancement. Different kinds of membranes, namely polymeric, hybrid, inorganic or supported, implement almost any material or chemical that may be required for testing. For example, coating allows modification of the membrane surface, applying a molecular layer in order to change surface characteristics of the membrane [53]. Appropriate separation mechanisms and target pollutants narrow the choices of the membrane [54]. For example, a steric exclusion separation membrane should have pores smaller than the target pollutant. Moreover, modifying the membrane surface with a target compound may improve the separation efficiency. Experiment conditions such as $\mathrm{pH}$, composition, temperature, water movements or pressure of the feed play major roles in separation. Usually, all mechanisms contribute to separation at once [55]. Notwithstanding, how intense each contribution may be, the separation mechanism may change during the process due to target pollutant effects. For example, an electrostatic repulsion membrane, based on pollutant rejection, may lose its surface properties during separation because of pollutant adsorption on the surface. This would lead to pollutant diffusion and cause the membrane to end up in permeable state [53]. The phenomenon is well known as the breakthrough curve of the membrane. Not only membrane separation tries to achieve $100 \%$ pollutant-free water, but full scale process application, energy evaluation (for membrane synthesis, and separation processes), the membrane's material cost and environmental assessment, must be taken into consideration. For illustration, reverse osmosis (RO) showed higher performance in rejection of ECs, reaching $100 \%$ in optimal conditions, compared to nanofiltration (NF). However, environmental assessment of these two 
filtration technologies showed that NF is much more ecofriendly compared to RO because of reduced energy demand [18].

The presented paper focuses on membrane technologies. Certain are nowadays used widely to produce clean water (see next part Membranes for water treatment). The advantage is low saturation of the selective barrier compared to sorbets, as well as decomposition that can take place separately from treated water. The membranes' function in eliminating ECs from water, usually exposes membranes to a large amount of water that passes through the selective barriers. These classical membranes aim at adequate performance, in terms of rejection, basing the separation mostly on size of the pores. That becomes highly challenging taking in consideration the large diversity of very small ECs. Albert Einstein said: "The world as we have created it is a process of our thinking. It cannot be changed without changing our thinking." This paper tries to offer unusual, stimulating discussion about different kinds of dense membranes for removal of ECs, confronting the pore size mechanism model with the solution-diffusion model.

\section{Membranes for Water Treatment (WT)}

The membrane processes listed in Table 2 are well known, or have already been mentioned, for WT [56-58]. Most of them focus on ion or particle removal.

Certainly, it is easier to transport only one compound, e.g., water, through the membrane than diverse ECs. Table 3 shows that the majority of the most used membrane processes in WT, listed in Table 2, apply water flux and only one EC's flux. Neither of the two options involves the flux of some other compounds or ions. 
Table 2. Membrane processes in water treatment (WT).

\begin{tabular}{|c|c|c|c|c|}
\hline Process & Nominal Pore Size & Driving Force & Membrane Type & Use \\
\hline $\begin{array}{l}\text { Microfiltration } \\
\text { (MF) }\end{array}$ & $0.05-10 \mu \mathrm{m}$ & Transmembrane pressure diff. $1-3$ bar & Porous, as/symmetric & Filtration \\
\hline $\begin{array}{l}\text { Ultrafiltration } \\
\text { (UF) }\end{array}$ & $0.001-0.005 \mu \mathrm{m}$ & Transmembrane pressure diff. $2-5$ bar & $\begin{array}{l}\text { Microporous asymmetric } \\
\quad(\mathrm{PES}, \mathrm{TF}, \mathrm{CA})^{*}\end{array}$ & $\begin{array}{l}\text { Filtr. protein and pathogen } \\
\qquad[59,60]\end{array}$ \\
\hline $\begin{array}{c}\text { Nanofiltration } \\
\text { (NF) }\end{array}$ & $<2 \mathrm{~nm}$ & Transmembrane pressure diff. $5-15$ bar & $\begin{array}{c}\text { Thin film comp., porous } \\
\text { (PA, PS)* }\end{array}$ & $\begin{array}{c}\text { Filtration-large ions } \\
\text { [61] }\end{array}$ \\
\hline $\begin{array}{l}\text { Forward Osmosis } \\
\text { (FO) }\end{array}$ & $0.5 \mathrm{~nm}$ & Osmotic pressure & $\begin{array}{l}\text { Asymm., thin film composite } \\
\text { (CTA })^{*}\end{array}$ & $\begin{array}{l}\text { Desalination } \\
\text { [62] }\end{array}$ \\
\hline $\begin{array}{l}\text { Reverse Osmosis } \\
\text { (RO) }\end{array}$ & $0.5 \mathrm{~nm}$ & Transmembrane pressure diff. $15-75$ bar & $\begin{array}{l}\text { Asymm., thin film composite } \\
\text { (PA, PBI) * }\end{array}$ & $\begin{array}{c}\text { Desalination } \\
{[60,61,63]}\end{array}$ \\
\hline $\begin{array}{l}\text { Electrodialysis } \\
\text { (ED) }\end{array}$ & $\mathrm{MW}<200 \mathrm{Da}$ & Electrical potential & Swollen gel, charged, symm. & Desalination \\
\hline $\begin{array}{l}\text { Electrodeionization } \\
\text { (EDI) }\end{array}$ & $\mathrm{MW}<200 \mathrm{Da}$ & Electrical potential & Swollen gel, charged, symm. & Desalination \\
\hline $\begin{array}{c}\text { Membrane degasification } \\
(\mathrm{MDg})\end{array}$ & $0.05-0.1 \mu \mathrm{m}$ & Transmembrane pressure diff., vacuum on perm. side & Porous, symmetric or asymmetric & Degasification \\
\hline $\begin{array}{l}\text { Membrane distillation } \\
\text { (MD) }\end{array}$ & - & Temperature and concentration gradient & Highly porous, symmetric & Desalination \\
\hline $\begin{array}{l}\text { Pervaporation } \\
\text { (PV) }\end{array}$ & - & Transmembrane fugacity difference & $\begin{array}{c}\text { Nonporous hydrophilic } \\
\text { (CS, SPEEK/PES) }{ }^{*} \\
\text { (PDMS/CERAM) }^{*} \\
(\mathrm{PEBA} / \mathrm{PU})^{*} \\
(\mathrm{PEI} / \mathrm{GO})^{*}\end{array}$ & $\begin{array}{c}\text { Desalination } \\
\text { [64-66] } \\
{[67]} \\
{[68]} \\
{[69]}\end{array}$ \\
\hline
\end{tabular}

${ }^{*}$ CA—Cellulose acetate; CTA—Cellulose tri-acetate; CS—chitosan; SPEEK—Sulfonated polyether ketone; PES—polyether sulfone; PEBA—polyether block amide; PU—polyurethane;

PEI-polyethyleneimine; GO—graphene oxide; PA—Polyamide; PBI—Polybenzimidazole. 
Table 3. Water and ECs flux through membrane in WT processes from Table 2. Neither of the two options involves the flux of any particles other than water or ECs.

\begin{tabular}{cccc}
\hline Membrane WT Process & Water Flux & ECs Flux & References \\
\hline MF & Yes & No & {$[70-72]$} \\
UF & Yes & No & {$[59,60]$} \\
NF & Yes & No & {$[61,73-77]$} \\
FO & Yes & No & {$[62,78-80]$} \\
RO & Yes & No & {$[60,61,63,74,81,82]$} \\
ED & No & No & Other \\
EDI & No & No & Other \\
MD & No & No & Other \\
MD & Yes & No & \\
PV & Yes & Yes & {$[57,68,69,83-87]$} \\
\hline
\end{tabular}

The most employed processes, e.g., NF, $\mathrm{RO}$ or FO, are supposed to retain contaminants and let the water pass through the selective barrier. Besides Donnan and adsorption, the separation is based mainly on a spherical exclusion mechanism [45,73]. Although defining a membrane pore is controversial, NF uses porous membranes with pore sizes of 1-2 nm, whereas FO and RO use even smaller sizes of less than $1 \mathrm{~nm}$. Such membranes may be very successful for many contaminants [18,88-90], but what about ECs? Will these membranes be the most suitable for EC ${ }^{\prime}$ removal, too? It is highly challenging to retain such small ECs with various molecular weights and such different properties. Up to now, the rejection of ECs by NF and RO has reached 40-100\% [59-61,74,77], depending on the membrane used, the experimental conditions etc. Here, the selectivity vs. effectiveness of membrane separations needs to be elucidated in more detail as follows.

\section{Selectivity vs. Effectiveness of Membrane Separation}

The factors influencing the membrane selectivity, mentioned in reviews dealing with membrane separation and ECs [18,91], are:

- Charge of the molecule

- Hydrophobicity of the separated molecule

- $\quad$ Size of the separated molecule

Two properties describe the affinity of the molecule to the membrane, which indicate if the molecule is able to diffuse through the membrane or is able to penetrate its pores. The solvent is the permeating species, because of its small molecule size, in the most employed processes such as $\mathrm{NF}, \mathrm{RO}$ or FO.

A detailed study discussing the factors influencing forward osmosis applied in the removal of ECs was presented by Coday et al. [78]. Their work showed that the experimental conditions may strongly influence the affinity of the target molecule to the membrane. They explained that the mechanism of separation is a combination of electrostatic repulsion, steric hindrance, the solubility and diffusivity of the molecule in the membrane and hydrophilic-hydrophobic forces between the solute and the membrane [78]. According to their work:

1. Rejection of nonionic hydrophilic ECs (e.g., paracetamol, caffeine, methylparaben) is a result of physical sieving.

2. Rejection of hydrophobic nonionic ECs (e.g., carbamazepine, estrone) is most influenced by the initial adsorption of the molecules on the membrane and, as the membrane gets saturated by the solute, the rejection decreases.

3. Positively charged ECs (propranolol, metroprolol) and negatively charged (ibuprofen, naproxen, diclofenac) rejection is connected with the electrostatic interactions between the molecule and the membrane surface, and with sieving. 
Considering that the membranes used for osmosis and $\mathrm{RO}$ are rather hydrophilic, the message received is not clear: hydrophobic compounds can adsorb on a hydrophilic membrane and saturate it, increasing its hydrophobicity and its permeability for the hydrophobic compounds. This was observed and described in detail by Nghiem et al. [75], who provided a complex study of the dependence of retention of three pharmaceuticals (ibuprofen, sulfamethoxazole and carbamazepine) on the $\mathrm{pH}$ of the feed solution, trying to explain the influence of electrostatic interactions between the molecule and the membrane on retention. A relatively hydrophilic TFC-SR2 nanofiltration membrane was used. The zeta potential of the membrane was measured and found to decrease with increasing $\mathrm{pH}$, from $+5 \mathrm{mV}$ at $\mathrm{pH}=2.5$ to $-10 \mathrm{mV}$ at $\mathrm{pH} \geq 5$. It was observed that at $\mathrm{pH}$ values where the molecules of the pharmaceuticals were negatively charged (lower than 4), their retention was low (meaning that they were permeating immediately through the membrane due to the strong electrostatic interactions with the positively charged membrane), except for ibuprofen, which was neutral and was adsorbed on the hydrophobic centers.

Acero et al. presented very interesting results illustrating how complicated the situation of the interaction between the separated substance and membrane can be. They used UF membranes with a large molecular weight cut-off (2000 kDa and more) and tested them with a water solution of hydroxybiphenyl. The molecular weight of hydroxybiphenyl is $170 \mathrm{~g} / \mathrm{mol}$ and it should completely pass through the membrane's pores if size exclusion was the only mechanism of rejection. However, the rejection of hydroxybiphenyl was nearly $100 \%$ because it was completely adsorbed on the membrane. This was proven also by a sorption experiment [59].

Sometimes, authors themselves are confused by their own results. Radjenovic et al. [61] presented precise work using NF and RO membranes, reaching high retention of all the tested substances with RO membranes. The only exceptions were gemifibrozil, and mefenamic acid. The authors' commented that these compounds are negatively charged and thus should have as high retention as the rest of the negatively charged emerging contaminants (due to electrostatic repulsion), and that there was no plausible explanation. Looking at the figures, it may be seen that the error bars for these two compounds ranged from $-20 \%$ to $100 \%$, so no explanation is necessary.

Studies on the role of the surface charge of the membrane were presented by Bellona and Drewes as well as by Childress and Elimelech in their much-cited works [76,92]. Childress and Elimelech extended the problem of the feed-solution chemistries, studying also the influence of the presence of surfactants. The electrostatic interactions are also influenced by the presence of background electrolyte. The chemistry of the feed solution always has to be studied when trying to apply membrane separation on ECs removal, because it will probably cause different results in laboratory tests with a model solution compared to tests with real wastewater or wastewater from different sources.

Unfortunately, all the mentioned interactions might be affected by membrane fouling in both the positive and negative senses. Studies connected with membrane fouling and its effect on separation have been published by numerous authors [79-81,93-95], reporting changes of the membrane surface due to fouling during the $\mathrm{RO}$ and nanofiltration processes. The authors found that, besides a decrease of the membrane flux, fouling also causes:

- Change of the surface charge (zeta potential).

- Change of the hydrophobicity of the membrane.

- Adsorption of some trace contaminant in the foulant.

- Change of the roughness of the membrane surface.

Nghiem et al. [96] worked on four different steroid hormones, tested on double-layered polymeric NF membranes. Average pore size was determined using neutral organic molecules and incorporated steric (size) exclusion out of convection and diffusion effects. Results showed that at the beginning of filtration, adsorption of the hormones to the membrane was the main removal process. Since the membrane pores' capacity was limited, once the membrane reached adsorption equilibrium, retention rate decreased due to the diffusion of hormones through the membrane. After membrane saturation, 
the pore size exclusion was less important for the separation compared with that of fresh membranes. A breakthrough curve, used for characterization of adsorption bed, can provide more information about membrane separation mechanisms in general [97]. Even though membrane adsorption reached equilibrium, the breakthrough concentration of the tested hormones remained low due to size excursion mechanisms [96]. Other effects become much more important, like diffusion of solute in the membrane and hydrogen bonding. Furthermore, the adsorbed solute can influence hydrophobicity of the membrane. All of those phenomena can influence the separation and retention qualities of the membrane. NF (membranes with a pore size of 1-2 nm) have shown to be insufficient to treat some ECs $[62,63,98]$. Thus, further processes are required to fully treat the permeate water of NF. Many NF processes are followed by some AOPs, or other degradation processes, to produce EC-free water [99-102]. Furthermore, chemical cleaning or regular backwashing of membranes may be a partial solution. However, fouling mitigation, for example antifouling membranes, is very challenging [103]. RO showed promising result in ECs reaching up to $100 \%$. Nevertheless, the process suffers from quick membrane fouling, pretreatment requirement and permeate water being excluded even from essential minerals [90]. This technology is applied to full-scale desalination. Pilot-scale results are more diverse than full scale results, mainly due to the change of hydraulic parameters [61].

Any possibility of worsening the quality of feed water influences the effectiveness of membrane separation. An example is the V\&A Waterfront desalination plant, installed as part of Day Zero emergency measures in Cape Town. Notwithstanding the capability of producing $2 \mathrm{ML}$ of potable water per day, its production is still struggling with poorer feed water quality than was originally expected. The selectivity of the membranes turns out to be insufficient because of unexpected pollutants in the feed. These are withdrawn by a huge stream of water, resulting in unsatisfactory quality of the drinking water produced [104].

From the viewpoint of environmental impact assessment, NF and RO show weaknesses in assessing different parameters like global warming potential, nutrient enrichment, fossil fuel usage, ozone depletion or toxicity [105]. NF require much less energy compared to RO [106]. However, NF cannot ensure high rejection for all ECs. RO impact assessment indicates high energy consumption and maintenance requirements $[107,108]$. Furthermore, the ECs' lode solution formed after NF or RO processes requires further treatment to reduce environment impact [82].

Considering all the factors influencing membrane selectivity, hydrophobic dense membranes (with target affinities to ECs) could solve the problem of complicated interactions and fouling, with no necessity to push a massive amount of wastewater through the membranes by high-pressure pumps. Despite having many other benefits, there is almost no use of such membrane processes in water depollution from ECs. The authors are unable to say whether this is because the most employed processes, like NF, RO or FO, are automatically tested for ECs elimination, or because obstacles exist that have not yet been overcome; no such publication has been found on the subject. The evaluation of advantages and disadvantages of well-known membrane materials that separate on the basis of particle size, versus dense hydrophobic membranes with target transport of emerging contaminants through a selective barrier, will be presented in next paragraph.

\section{Dense Membrane Processes with Targeted Transport of ECs}

The composition of membranes in WT dealing with ECs is heading towards more and more dense materials (see higher selectivity of more dense RO membranes than NF ones, above). Dense membranes are known for their higher selectivity compared to porous constituents. Their transport process can be described as a solution-diffusion model. Still, even dense RO membranes provide separation based on pore size. Avoiding the permeation of water through the membrane and enhancing the transport of ECs may be achieved by using hydrophobic dense membranes. The authors simplify, in Table 4, the pluses and minuses of membrane separation based on pore size and on target transport of ECs. 
Table 4. Pluses and minuses of membrane separation based on pore size and on target transport of ECs through hydrophobic dense membranes.

\begin{tabular}{cccc}
\hline Perspective & $\begin{array}{c}\text { Membrane Separation } \\
\text { Based on Pore Size }\end{array}$ & $\begin{array}{c}\text { Separation Based on } \\
\text { Target Transport of ECs }\end{array}$ & Note \\
\hline Rate of the process & ++ & - & $(\mathrm{a})$ \\
Economics & ++ & - & $(\mathrm{b})$ \\
Available on the market & + & - & $(\mathrm{c})$ \\
Number of membrane types needed & + & - & $(\mathrm{d})$ \\
Prediction & - & ++ & $(\mathrm{e})$ \\
Treated water & - & + & $(\mathrm{f})$ \\
Fouling & - & + & $(\mathrm{g})$ \\
Pressure & - & $(\mathrm{h})$ \\
\hline
\end{tabular}

Note (a-c) Membrane separation based on pore size are the most employed membrane processes in WT such as UF, NF or RO. The processes are well described, membranes are available and the separation is fast. These processes were, however, not primarily designed for removal of ECs. There are several new studies trying to clarify whether UF, NF and RO may be successfully applied in removal of ECs. The rejection of different ECs by NF and RO were from 40 to $100 \%[59-61,74,77]$ depending on EC. Dense hydrophobic membranes for target transport of ECs (without the pore size mechanism) were not yet used.

Note (d) The advantage of classical processes, with separation based on pore size, is that only one membrane type is needed for treatment of all contaminants, but insufficient selectivity would lead to additional separation parts. Using dense polymeric membranes for target transport of ECs, several different types would be needed.

Note (e) Whether the molecule of EC is retained by the RO or NF membrane depends on the characteristics of the molecule, namely its charge, hydrophobicity and size. Which molecules will be retained, and which not, cannot be well predicted because it is not only a matter of sieving (as the method was originally designed). Example: "The molecular weight of the Hydroxybiphenyl is $170 \mathrm{~g} / \mathrm{mol}$ and it should completely pass through the membrane's pores if the size exclusion was the only mechanism of rejection. However, the rejection of Hydroxybiphenyl was nearly $100 \%$ because it was completely adsorbed on the membrane" [59]. Dense polymeric membranes are predictable for any kind of molecule.

Note (f) After treatment by RO we get nearly UP water and brine full of different ECs compounds. Such water cannot be released to the environment or drunk [104]. It must be remineralized. No need when using targeted dense membranes because only the contaminants would be removed, and the natural composition of water will remain. In the case of water being contaminated mainly by one or two pollutants, it would be interesting to eliminate only these instead of the entire elimination of the water content (with uncertain results).

Note (g) Membrane separation based on pore size suffers by fouling that can influence the interactions between the molecule and the membrane and, consequently, also the quality of rejection [81]; see also example in Note (e). The water passes along the dense polymeric membranes and, therefore, no fouling occurs.

The removal of ECs by processes using dense membranes deserves attention of researchers. On one hand, classical technologies, e.g., RO, are commercially ahead and adapting for ECs removal. On the other hand, the membrane processes that may be potentially used for target transport of ECs (applying hydrophobic nonporous membranes), are not yet widely known for such treatment. Still, they are already recognized in other fields such as pervaporation (PV), membrane extraction and petraction, which is a special case of dialysis that uses the nonporous membranes. 


\subsection{Pervaporation}

PV is a method for the separation of liquids through a membrane that is in contact with a liquid mixture on the feed side while a vacuum is applied on the permeate side. A phase change of the permeating component occurs as a result of such operation conditions. It enters the membrane as a liquid and leaves the membrane as vapor. The vapor is then usually trapped by refrigeration. Pervaporation processes are widely used for compound separation, especially in aroma and flavors extraction [64,109,110], azeotropic organo-aqua mixture separation, during chemical reactions [111], desalination [65,87], volatile organic compounds (VOCs) removal [66], thermally sensitive substances, dehydration of solvents and compounds recovery. The advantages of this technology are its low energy consumption [112] and separation of trace concentrated solutions [113]. Unlike most known separation methods for filtration, PV and pertraction rely on dense membrane selectivity and involve different separation mechanisms: adsorption in the feed side dissolution, diffusion in the membrane and desorption to the permeate side [70,71]. This nonexpansive separation technology has replaced other processes due to its low energy consumption $[67,114]$, involving sixty-five percent more energy saving than distillation [115] without fouling and intensive maintenance problems. The high selectivity of pervaporation membrane can produce high purity permeate [112]. The permeate is a recovered solute and can be used again thanks to its high purity in the case of a single target compound. PV can also be used for a broad range of aromatic molecules, for example, aroma and flavors extraction or in wastewater purification from trace and persistent compounds $[114,116]$. The processes do not need high pressure to push huge amounts of water through the membrane as in filtrations processes. A vacuum is applied on the permeate side which creates flux through the membrane in the case of PV, but mainly the processes are based on compound and membrane affinity [117]. PV is now being tested for water desalination $[57,68,69,83,84,87]$.

The rejection ratio, $R$, of the component $i$ by the membrane is defined as the fraction of solute kept at the feed side regardless of membrane area or compound concentration. This factor shows a general rejection of the membrane toward the compound at a specific time $t$ of the separation. Plotting rejection ratio as a function of time visualizes the breakthrough moment of the membrane [97].

$$
R_{i, t}=1-C_{p, i . t} / C_{f, i, t 0}
$$

where $C_{p, i, t}$ and $C_{f, i, t 0}$ are the concentrations of the compound $i$ on the permeate side at the moment $t$ and initial concentration of the feed side, respectively.

The permeation flux $J$ of the component $i$ through a dense membrane (Equation (2)) is defined as the amount of the permeating substance related to the membrane area $(A)$ per unit of time $(t)[111,118]$ :

$$
J_{i}=\frac{n_{i}}{A t}
$$

The permeation flux is influenced by:

(1) Membrane thickness.

(2) Driving force.

(3) Permeability of the membrane.

The influence of the membrane thickness is easy to understand, the thicker the membrane the lower the permeation flux. Driving force and permeability are more complicated.

Permeability (Equation (3)) is the value that describes the affinity of the membrane material to the permeating component, and vice versa. In the case of the solution diffusion transport mechanism, it is usually defined as a product of the solubility (sorption) coefficient $S$ of the component in the membrane and the diffusion coefficient (diffusivity) $D$ of the component in the membrane:

$$
P_{i}=D_{i} \times S_{i}
$$


The solubility and diffusivity of the component in the membrane are easily measurable values but they are hard to predict. They are determined by certain interactions and similarities between the membrane and the permeating components, as discussed earlier.

The last thing that influences the PV flux of the permeating component is the driving force. Generally, the driving force is defined as the difference of the chemical potential of the particular component across the membrane. In the case of PV, the chemical potential difference is transformed into the difference between the fugacity of the permeating component in the liquid on the feed side of the membrane (Equation (4)) and the fugacity of its vapor on the permeate side of the membrane in the gaseous phase (Equation (5)).

$$
f_{i}^{l}=x_{i} \gamma_{i} p_{i}^{\text {sat }}
$$

where $x_{i}$ is the molar fraction of the component in the liquid phase, $\gamma_{i}$ is the activity coefficient of the component in the solution and $p_{i}^{\text {sat }}$ is the saturated vapor pressure of the component.

$$
f_{i}^{g}=y_{i} p(5)
$$

$y_{i}$ is the molar fraction of the component in the gaseous phase.

The permeation flux is then expressed as:

$$
J_{i}=\frac{P_{i}}{l}\left(x_{i} \gamma_{i} p_{i}^{s a t}-y^{i} p\right)
$$

where $p_{i}$ is the permeability of the membrane for the permeating component and $l$ is the membrane thickness [111,118].

As mentioned in the introduction, ECs are a huge group of substances of different kinds. Table 1 shows selected compounds commonly declared to be ECs $[13,16,119,120]$, having differences in their molecular weight (even though compounds of lower molecular weight were chosen), melting point, vapor pressure and water octanol partition coefficient. Their water solubility also varies strongly. From the point of view of PV, compounds with higher vapor pressure and higher water solubility are more suitable because of their higher permeation flux probability. Their vapor pressure and solubility are temperature-dependent, so their values may be influenced by raising the temperature of the membrane or the solution, though such an approach always needs to be considered with respect to the economy of the process.

There have been trials utilizing the pervaporation process for the removal of ECs from water. Higuchi et al. tried to use PV to remove 1,2-dibromo-3-chloropropane (DBCP) from water with a PDMS membrane [85]. The authors performed the pervaporation experiment using an aqueous solution of $10 \mathrm{ppm}$ of DBCP. The membrane area was $15.2 \mathrm{~cm}^{2}$ and the membrane thickness was $2 \mu \mathrm{m}$. Because of the low vapor pressure of $\mathrm{DBCP}$, the authors decided to heat the membrane to $150{ }^{\circ} \mathrm{C}$ to enhance the pervaporation flux. They presented the values of pervaporation flux calculated from the difference between the initial concentration of the DBCP in the feed and the concentration after the pervaporation experiment. They did not say whether anything was found in the cold trap after the PV. The concentration of the DBCP decreased after 10 hours of PV from $10 \mathrm{ppm}$ to $2 \mathrm{ppm}$, but this could have been caused by the sorption of the DCBP in the membrane only, without passing through, because of the very low concentration of the substance studied. This conclusion is supported by the fact that the same group of authors, one year later, presented work dealing only with the selective sorption of emerging contaminants by a PDMS membrane from water and human milk, where DCBP was one of the studied compounds [121]. Higuchi et al. [86] also tried to remove dioctyl phthalate and butylated hydroxytoluene from mineral water by PV through a PDMS membrane. They used commercially available mineral water in glass and polyethylene terephthalate (PET) bottles. The initial concentrations of ECs in the feed solutions were less than $1 \mathrm{ppm}$. The separation factor was more or less 100 for all the tested samples. The significant part of this work is the addition of theory and the introduction of a linear correlation between the separation factor of the PDMS membrane, log Kow 
("hydrophobicity") and the vapor pressure of the ECs: the higher the product of the vapor pressure and $\log$ Kow, the higher the separation factor.

$\mathrm{PV}$ is thus able to separate lighter and more volatile ECs from water. However, it is not suitable for less or nonvolatile ECs, yet, the process is suitable where separation is difficult and other membrane processes are insufficient.

\subsection{Pertraction}

Pertraction is a membrane process using dense or liquid membranes, and the principles are similar to PV. The main difference is that there is liquid on both sides of the membrane: the donor, feed solution on one side and the acceptor solution on the other side. The driving force is also the chemical potential difference, but here it is transformed into the difference of the activity of the particular component across the membrane or, in the simplest case, the difference in the concentration of the permeating component $\left(c_{i}^{d}-c_{i}^{a}\right)$. The permeation flux (Equation (7)) and permeability may be calculated in the same way as in the case of PV.

$$
J_{i}=\frac{P_{i}}{l}\left(c_{i}^{d}-c_{i}^{a}\right)
$$

At laboratory scale, pertraction is often performed as a batch process that causes a continual decrease of the driving force until the concentrations on both sides of the membrane are equal. A low concentration of ECs will worsen it. This can be solved by using a sweep liquid, which should be recycled in the process (e.g., water that can be redistilled so that residues of the ECs, which have a much higher boiling point, would remain in the solid phase). Perfect stirring is necessary to keep both solutions homogeneous and thus the driving force maximal, and to avoid concentration polarization on both sides of the membrane.

The word pertraction in connection with the separation of pharmaceuticals, ECs, endocrine disruptors etc., is hard to find. But inspiration can be drawn from studies on transdermal permeation of drugs. Such tests are performed with Franz diffusion cells and use thin dense membranes like silicone. Waters et al. [122] tested the transport of five different drugs (benzoic acid, benzotriazole, ibuprofen, ketoprofen and lidocaine), which were chosen because of their different pKa and log Kow, through a silicone membrane at $\mathrm{pH}$ values from 4.5 to 8.5 . It was found that, due to the hydrophobic character of the membrane, the substances with high pKa (those present mostly in un-ionized form) permeated the membrane much more easily. It was also found that ibuprofen, despite its quite high acidity and being almost fully dissociated at all the tested $\mathrm{pH}$ values, showed high permeation fluxes compared to other substances because it is strongly hydrophobic. That was in agreement with previously presented facts. The same research group tested the influence of the presence of surfactants of different types in the feed solution during permeation [123]. They described the possible interactions of the surfactant and the membrane surface, and how the surfactants create a charged layer on the membrane, which affects the electrostatic interactions between the membrane and the permeating component.

A slight terminological diversity occurred during the review process about the interaction of the selected substances of interest [124]. Contemporary ECs are mentioned as trace organic compounds, endocrine disruptors and drugs. An extensive and detailed study was found, performed by Garret et al. in 1968, who, for example, used a key word drug connected with diffusion and polymeric membranes [125-127]. The authors presented the diffusion of different drugs through a silastic membrane. This process may also be called pertraction because they used a liquid receiving phase (acceptor solution). The authors also introduced the $\mathrm{pH}$ partition hypothesis, which takes into account the fact that only uncharged (un-ionized, not dissociated) compounds interact with the uncharged membrane. This was verified experimentally by the fact that when the $\mathrm{pH}$ of the feed solution was equal to the $\mathrm{pKa}$ of the studied drug (meaning that one half of the compound was in ionized form), the apparent diffusion constant (permeability) decreased by one half. The previously cited authors also declared that the interaction of the membrane and the permeating component was influenced by the electrostatic interaction and $\mathrm{pH}$ of the solution, and a study presented by Garret et al. 
gave mathematical evidence for this fact. Besides that, the authors screened the permeability of different polymeric membranes for different drugs from different solvents finding, for example, that polyethylene was permeable to acetaminophen in aqueous solution, silastic membrane to acetaminophen from all used solvents and progesterone from ethanol, summarizing it in a simple sentence: "solid polymeric membranes are permeable to uncharged organic molecules which are lipophilic".

In general, pertraction can be highly selective and thus may not lead to losses of, for example, some important ions from water.

\subsection{Membrane Extraction}

Membrane extraction was developed and tested for analytics. The aim is to increase the concentration of an analyte in a sample by moving it from a worse solvent to a better one. It allows a transfer of the analyte from one solvent to another, avoiding mixing of the two solvents by dividing them with a nonporous membrane. In this case, the molecule is transported to the membrane in the donor phase mainly by convection (shaking, stirring), then the molecule is dissolved in the membrane. It diffuses through the membrane and dissolves in the second solvent. This solvent can be easily selected using solubility or partition coefficient data. Considering the batch mode of the separation, the process can be described as follows.

The membrane flux is given by Fick's law:

$$
J_{i}=\frac{D_{i}}{l}\left(c_{\text {water }}^{\text {membrane }}-c_{\text {organic }}^{\text {membrane }}\right)
$$

where $c_{\text {water }}^{\text {membrane }}$ is the concentration of the separated compounds on the water phase side of the membrane and $c_{\text {organic }}^{\text {membrane }}$ on the organic phase side of the membrane.

$$
c_{i \text { water }}^{\text {membrane }}=S_{i w} * c_{i \text { water }}^{\text {bulk }}
$$

where $S_{i w}$ is the sorption coefficient of the separated component from the aqueous phase, which is a measurable value.

$$
c_{i \text { organic }}^{\text {membrane }}=S_{i o} * c_{i \text { organic }}^{\text {bulk }}
$$

where $S_{i o}$ is the sorption coefficient of the separated component in the organic phase.

The fact that there are different solvents on both sides of the membrane is reflected also in the mathematical description of the process, because of the different sorption coefficients. It is essential to know both sorption coefficients because this influences strongly the driving force of diffusion and they cannot be hidden in some overall mass transfer coefficient as in PV and pertraction. The factors leading to successful separation are the same as in previous cases: reasonable diffusivity of the component through the membrane and good affinity of the component to the membrane material. Enhancement of the separation here is provided by the better solvent used as an acceptor phase.

Swelling of the membrane in the organic solvent may play an important role in this process. Swelling causes the membrane thickness to increase but also increases the diffusivity of the component in the membrane because the polymeric chains in the membrane material recede from each other. In addition, the organic solvent gets closer to the separated component during swelling.

The solubility of many ECs in other solvents is several orders of magnitude higher than in water.

To illustrate the difference between the solubility of ECs in water and in, for example, ethanol, a simple mathematical exercise may be done. The concentrations of ibuprofen and ethinyl estradiol in two particular studies from the Czech Republic were taken and it was calculated how much of the studied water could be theoretically extracted with $1 \mathrm{~L}$ of Ethanol. The results are presented in Table 5. 
Table 5. Illustration of vast differences between the solubility of ECs (ethinyl estradiol and ibuprofen) in water and ethanol.

\begin{tabular}{cccc}
\hline Parameters & Units & Ethinyl Estradiol & Ibuprofen \\
\hline Water solubility & $\mathrm{g} / \mathrm{L}$ & $1.13 \times 10^{-2}$ & $2.10 \times 10^{-2}$ \\
Ethanol solubility & $\mathrm{g} / \mathrm{L}$ & 50 & 60 \\
c in particular case & $\mathrm{g} / \mathrm{L}$ & $5.10 \times 10^{-8}$ & $9.90 \times 10^{-6}$ \\
Reference & - & {$[77]$} & {$[15]$} \\
$\begin{array}{c}\text { Amount of water from particular case } \\
\text { extractable by 1 L of Ethanol }\end{array}$ & $\mathrm{m}^{3}$ & $9.8 \times 10^{-5}$ & 6060 \\
\hline
\end{tabular}

Membrane-assisted extraction is usually mentioned in connection with the analysis of trace compounds in water or environmental samples [128-132]. Concrete examples include the extraction of phenolic compounds from water by silicone rubber [133], UV filters by a low-density polyethylene (LDPE) membrane [134,135], parabens by an LDPE membrane [136], salbutamol and terbutaline by a supported liquid membrane with Aliquot 335 as a carrier [137], and polycyclic musk by an LDPE membrane [138].

A very complex and comprehensive review was presented by Hylton and Mitra [139]. This publication is important because it confirms beyond doubt that using nonporous membranes for the separation of hydrophobic components from water works and is used widely, but in another field than suggested in this present review. Another comprehensive review on membrane extraction in analytical chemistry was published by Jonsson et al. [140]. According to their work, an automated system for nonporous membrane extraction for sample preparation was developed and tested. Although liquid membranes are often used in pertraction and membrane extraction, their employment is certainly not convenient for water purification. There is a risk of possible contamination of purified water by the liquid from the membrane.

Membrane extraction with nonporous polymeric membrane into some convenient solvent could, therefore, be another possible method for removal of ECs from water. Membrane materials such as ordinary LDPE or silicone rubber may be effective enough. The solvent would have to be continually regenerated during the process. On the other hand, only a small amount of solvent (compared to the volume of the feed phase) would be necessary. The advantages and disadvantages are similar to previous alternatives, eliminating ECs from water though membranes. The process would be rather slow, requiring a long contact time and large membrane area. That would be the price for aiming for the highest selectivity and avoiding leakage linked to the immense water flux through a membrane. In addition, the membrane would not be exposed to high pressures. Last, but not least, the target compounds may be removed from the water without losing valuable ions.

\section{Conclusions}

The authors fully agree with Taheran et al. that any method which only creates a more or less concentrated stream, including the membrane separations, cannot be used solely. Still, the popularity of membrane processes in water depollution is great, especially those with elevated water flux through the membranes. This paper compared and discussed a classical pore size mechanism approach of popular nondense (porous) or quasi-dense hydrophilic membranes versus real-dense membranes without pores. It underlines the advantage of, for example, RO being commercially ahead, notwithstanding new adaptation for ECs removal. On the other hand, it confirms beyond doubt that using real-porous membranes for the separation of hydrophobic components from water works, and is used widely, but in another field than suggested here.

Use of real-dense membranes is proposed by the authors as a perspective way to reach the highest selectivity in elimination of ECs elimination. Such membranes are more suitable for flux of ECs through the membrane instead of water Therefore, a hydrophobic separation material would be preferred. Their limitation will surely be connected to the driving force. However, they offer better 
water/target compounds selectivity than any membrane separating principally on size of the pores (even though they are so small that they are considered negligible). In addition, pressurizing the feed stream would not be necessary. The membranes could be suitable for purposes where high quality takes priority over large quantities. Target transport through the membrane can be suitable for each kind of EC, namely nonionic hydrophilic, nonionic hydrophobic, positively or negatively charged ECs. The real-dense membrane can be well programed for any group of ECs or a specific compound. Knowing the physicochemical properties of the membrane and the separated molecules, appropriate membranes may be employed and allow the emerging contaminants to be concentrated for the next step: safe degradation out of the treated water. The amount of eliminated ECs is not limited as in the case of sorbents. Moreover, concentrating the ECs might help to analyze their composition in water by means of common measurements, which are insufficient when the concentration is too low. As for convenient processes, PV may be used for more volatile compounds, and pertraction and membrane extraction for all ECs.

Author Contributions: Conceptualization, J.G. and M.K.; investigation, M.B.; writing—original draft preparation, M.K.; writing - review and editing, J.G.; funding acquisition, J.G. All authors have read and agreed to the published version of the manuscript.

Funding: The authors gratefully acknowledge Czech Science Foundation grant $\mathrm{N}^{\circ} 19-08153 \mathrm{Y}$ for financial support.

Conflicts of Interest: The authors declare no conflict of interest.

\section{List of Abbreviations}

\begin{tabular}{|c|c|}
\hline AOPs & advanced oxidation processes \\
\hline CA & cellulose acetate \\
\hline CNTs & carbon nanotubes \\
\hline CS & chitosan \\
\hline CTA & cellulose tri-acetate \\
\hline DBCP & 1,2-dibromo-3-chloropropane \\
\hline ECs & emerging contaminants \\
\hline EDI & electrodeionization \\
\hline FO & forward osmosis \\
\hline GO & graphene oxide \\
\hline $\mathrm{HCH}$ & hexachlorocyclohexane \\
\hline LDPE & low-density polyethylene \\
\hline MD & membrane distillation \\
\hline $\mathrm{MDg}$ & membrane degasification \\
\hline MF & microfiltration \\
\hline MOFs & metal organic frameworks \\
\hline NF & nanofiltration \\
\hline PA & polyamide \\
\hline PBI & polybenzimidazole \\
\hline PDMS & polydimethyl siloxane \\
\hline PEBA & polyether block amide \\
\hline PEI & polyethyleneimine \\
\hline PES & polyether sulfone \\
\hline PET & polyethylene terephthalate \\
\hline PU & polyurethane \\
\hline PV & pervaporation \\
\hline RO & reverse osmosis \\
\hline SPEEK & sulfonated poly ether ether ketone \\
\hline UF & ultrafiltration \\
\hline WT & water treatment \\
\hline
\end{tabular}




\section{References}

1. Aus der Beek, T.; Weber, F.A.; Bergmann, A.; Hickmann, S.; Ebert, I.; Hein, A.; Küster, A. Pharmaceuticals in the environment-Global occurrences and perspectives. Environ. Toxicol. Chem. 2016, 35, 823-835. [CrossRef] [PubMed]

2. Cairns, J.; Dickson, K.L.; Maki, A.W. Estimating the hazard of chemical substances to aquatic life. Hydrobiologia 1979, 64, 157-166. [CrossRef]

3. Halling-Sørensen, B.; Nielsen, S.N.; Lanzky, P.; Ingerslev, F.; Lützhøft, H.H.; Jørgensen, S. Occurrence, fate and effects of pharmaceutical substances in the environment-A review. Chemosphere 1998, 36, 357-393. [CrossRef]

4. Chander, V.; Sharma, B.; Negi, V.; Aswal, R.S.; Singh, P.; Singh, R.; Dobhal, R. Pharmaceutical compounds in drinking water. J. Xenobiotics 2016, 6, 5774. [CrossRef] [PubMed]

5. Mooney, D.; Richards, K.G.; Danaher, M.; Grant, J.; Gill, L.; Mellander, P.E.; Coxon, C.E. An investigation of anticoccidial veterinary drugs as emerging organic contaminants in groundwater. Sci. Total Environ. 2020, 746, 141116. [CrossRef]

6. Lin, X.; Xu, J.; Keller, A.A.; He, L.; Gu, Y.; Zheng, W.; Sun, D.; Lu, Z.; Huang, J.; Huang, X.; et al. Occurrence and risk assessment of emerging contaminants in a water reclamation and ecological reuse project. Sci. Total Environ. 2020, 744, 140977. [CrossRef]

7. Mazille, F.; Schoettl, T.; Klamerth, N.; Malato, S.; Pulgarin, C. Field solar degradation of pesticides and emerging water contaminants mediated by polymer films containing titanium and iron oxide with synergistic heterogeneous photocatalytic activity at neutral pH. Water Res. 2010, 44, 3029-3038. [CrossRef]

8. Matamoros, V.; Caiola, N.; Rosales, V.; Hernández, O.; Ibáñez, C. The role of rice fields and constructed wetlands as a source and a sink of pesticides and contaminants of emerging concern: Full-scale evaluation. Ecol. Eng. 2020, 156, 105971. [CrossRef]

9. Badea, S.L.; Geana, E.I.; Niculescu, V.C.; Ionete, R.E. Recent progresses in analytical GC and LC mass spectrometric based-methods for the detection of emerging chlorinated and brominated contaminants and their transformation products in aquatic environment. Sci. Total Environ. 2020, 722, 137914. [CrossRef]

10. Diuzheva, A.; Dejmkova, H.; Fischer, J.; Andruch, V. Simultaneous determination of three carbamate pesticides using vortex-assisted liquid-liquid microextraction combined with HPLC-amperometric detection. Microchem. J. 2019, 150, 104071. [CrossRef]

11. Vieira, W.T.; de Farias, M.B.; Spaolonzi, M.P.; da Silva, M.G.C.; Vieira, M.G.A. Removal of endocrine disruptors in waters by adsorption, membrane filtration and biodegradation. A review. Environ. Chem. Lett. 2020, 18, 1113-1143. [CrossRef]

12. Jung, C.; Son, A.; Her, N.; Zoh, K.D.; Cho, J.; Yoon, Y. Removal of endocrine disrupting compounds, pharmaceuticals, and personal care products in water using carbon nanotubes: A review. J. Ind. Eng. Chem. 2015, 27, 1-11. [CrossRef]

13. Wang, J.L.; Wang, S.Z. Removal of pharmaceuticals and personal care products (PPCPs) from wastewater: A review. J. Environ. Manag. 2016, 182, 620-640. [CrossRef] [PubMed]

14. Rodriguez-Narvaez, O.M.; Peralta-Hernandez, J.M.; Goonetilleke, A.; Bandala, E.R. Treatment technologies for emerging contaminants in water: A review. Chem. Eng. J. 2017, 323, 361-380. [CrossRef]

15. Yang, Y.; Ok, Y.S.; Kim, K.H.; Kwon, E.E.; Tsang, Y.F. Occurrences and removal of pharmaceuticals and personal care products (PPCPs) in drinking water and water/sewage treatment plants: A review. Sci. Total Environ. 2017, 596, 303-320. [CrossRef] [PubMed]

16. Barrios-Estrada, C.; Rostro-Alanis, M.D.; Munoz-Gutierrez, B.D.; Iqbal, H.M.N.; Kannan, S.; Parra-Saldivar, R. Emergent contaminants: Endocrine disruptors and their laccase-assisted degradation-A review. Sci. Total Environ. 2018, 612, 1516-1531. [CrossRef]

17. Kanakaraju, D.; Glass, B.D.; Oelgemoller, M. Advanced oxidation process-mediated removal of pharmaceuticals from water: A review. J. Environ. Manag. 2018, 219, 189-207. [CrossRef]

18. Kim, S.; Chu, K.H.; Al-Hamadani, Y.A.J.; Park, C.M.; Jang, M.; Kim, D.H.; Yu, M.; Heo, J.; Yoon, Y. Removal of contaminants of emerging concern by membranes in water and wastewater: A review. Chem. Eng. J. 2018, 335, 896-914. [CrossRef]

19. Galindo-Miranda, J.M.; Guizar-Gonzalez, C.; Becerril-Bravo, E.J.; Moeller-Chavez, G.; Leon-Becerril, E.; Vallejo-Rodriguez, R. Occurrence of emerging contaminants in environmental surface waters and their analytical methodology-A review. Water Sci. Technol. Water Supply 2019, 19, 1871-1884. [CrossRef] 
20. Buser, H.R.; Poiger, T.; Muller, M.D. Occurrence and environmental behavior of the chiral pharmaceutical drug ibuprofen in surface waters and in wastewater. Environ. Sci. Technol. 1999, 33, 2529-2535. [CrossRef]

21. Golovko, O.; Kumar, V.; Fedorova, G.; Randak, T.; Grabic, R. Removal and seasonal variability of selected analgesics/anti-inflammatory, anti-hypertensive/cardiovascular pharmaceuticals and UV filters in wastewater treatment plant. Environ. Sci. Pollut. Res. 2014, 21, 7578-7585. [CrossRef] [PubMed]

22. Rozman, D.; Hrkal, Z.; Váňa, M.; Vymazal, J.; Boukalová, Z. Occurrence of Pharmaceuticals in Wastewater and Their Interaction with Shallow Aquifers: A Case Study of Horní Beřkovice, Czech Republic. Water 2017, 9, 218. [CrossRef]

23. Santos, J.L.; Aparicio, I.; Alonso, E. Occurrence and risk assessment of pharmaceutically active compounds in wastewater treatment plants. A case study: Seville city (Spain). Environ. Int. 2007, 33, 596-601. [CrossRef] [PubMed]

24. Ternes, T.A.; Herrmann, N.; Bonerz, M.; Knacker, T.; Siegrist, H.; Joss, A. A rapid method to measure the solid-water distribution coefficient $(\mathrm{K}-\mathrm{d})$ for pharmaceuticals and musk fragrances in sewage sludge. Water Res. 2004, 38, 4075-4084. [CrossRef]

25. Vymazal, J.; Bfezinova, T. The use of constructed wetlands for removal of pesticides from agricultural runoff and drainage: A review. Environ. Int. 2015, 75, 11-20. [CrossRef]

26. Vymazal, J.; Brezinova, T.; Kozeluh, M. Occurrence and removal of estrogens, progesterone and testosterone in three constructed wetlands treating municipal sewage in the Czech Republic. Sci. Total Environ. 2015, 536, 625-631. [CrossRef]

27. Vymazal, J.; Brezinova, T.D.; Kozeluh, M.; Kule, L. Occurrence and removal of pharmaceuticals in four full-scale constructed wetlands in the Czech Republic-The first year of monitoring. Ecol. Eng. 2017, 98, 354-364. [CrossRef]

28. Kumar, P.; Bansal, V.; Kim, K.H.; Kwon, E.E. Metal-organic frameworks (MOFs) as futuristic options for wastewater treatment. J. Ind. Eng. Chem. 2018, 62, 130-145. [CrossRef]

29. Zhuo, N.; Lan, Y.Q.; Yang, W.B.; Yang, Z.; Li, X.M.; Zhou, X.; Liu, Y.; Shen, J.C.; Zhang, X.T. Adsorption of three selected pharmaceuticals and personal care products (PPCPs) onto MIL-101(Cr)/natural polymer composite beads. Sep. Purif. Technol. 2017, 177, 272-280. [CrossRef]

30. Sophia, A.C.; Lima, E.C. Removal of emerging contaminants from the environment by adsorption. Ecotoxicol. Environ. Saf. 2018, 150,1-17. [CrossRef]

31. Cukierman, A.L.; Nunell, G.V.; Bonelli, P.R. Removal of emerging pollutants from water through adsorption onto carbon-based materials. In Emerging and Nanomaterial Contaminants in Wastewater; Mishra, A.K., Anawar, H.M.D., Drouiche, N., Eds.; Elsevier: Amsterdam, The Netherlands, 2019; Chapter 7; pp. 159-213. [CrossRef]

32. Delgado-Moreno, L.; Bazhari, S.; Nogales, R.; Romero, E. Innovative application of biobed bioremediation systems to remove emerging contaminants: Adsorption, degradation and bioaccesibility. Sci. Total Environ. 2019, 651, 990-997. [CrossRef]

33. Gil, A.; Taoufik, N.; García, A.M.; Korili, S.A. Comparative removal of emerging contaminants from aqueous solution by adsorption on an activated carbon. Environ. Technol. 2019, 40, 3017-3030. [CrossRef] [PubMed]

34. Chen, W.-H.; Huang, J.-R. Adsorption of organic including pharmaceutical and inorganic contaminants in water toward graphene-based materials. In Contaminants of Emerging Concern in Water and Wastewater; Hernández-Maldonado, A.J., Blaney, L., Eds.; Butterworth-Heinemann: Oxford, UK, 2020; Chapter 3; pp. 93-113. [CrossRef]

35. Dhaka, S.; Kumar, R.; Deep, A.; Kurade, M.B.; Ji, S.-W.; Jeon, B.-H. Metal-organic frameworks (MOFs) for the removal of emerging contaminants from aquatic environments. Coord. Chem. Rev. 2019, 380, 330-352. [CrossRef]

36. Yin, C.-Y. Emerging usage of plant-based coagulants for water and wastewater treatment. Process Biochem. 2010, 45, 1437-1444. [CrossRef]

37. Villaseñor-Basulto, D.L.; Astudillo-Sánchez, P.D.; del Real-Olvera, J.; Bandala, E.R. Wastewater treatment using Moringa oleifera Lam seeds: A review. J. Water Process Eng. 2018, 23, 151-164. [CrossRef]

38. Anguille, S.; Moulin, P.; Testa, F. Device for Extraction of Pollutants by Multichannel Tubular Membrane. U.S. Patent 10,137,385, 27 November 2018.

39. Maoqi, F. Biochar Treatment of Contaminated Water. U.S. Patent 10,246,347, 2 April 2019. 
40. Nickelsen, M.G.; Woodard, S.E. Sustainable System and Method for Removing and Concentrating per-and Polyfluoroalkyl Substances (PFAS) from Water. U.S. Patent 10,287,185, 14 May 2019.

41. Suri, R.P.; Bhattarai, B. Silica Particles Coated with $\beta$-Cyclodextrin for the Removal of Emerging Contaminants from Wastewater. U.S. Patent 9,828,458, 28 November 2017.

42. Velazquez, F.R.; Alos, V.F.; Perez, O.P. Synthesis of Biocomposite Alginate-Chitosan-Magnetite Nanoparticle Beads for Removal of Organic Persistent Contaminants from Water Systems. U.S. Patent 10,569,253, 25 February 2020.

43. Yu, M. Ultrathin, Graphene-Based Membranes for Water Treatment and Methods of their Formation and Use. U.S. Patent 10,092,882, 9 October 2018.

44. Espindola, J.C.; Vilar, V.J.P. Innovative light -driven chemical/catalytic reactors towards contaminants of emerging concern mitigation: A review. Chem. Eng. J. 2020, 394. [CrossRef]

45. Rizzo, L.; Malato, S.; Antakyali, D.; Beretsou, V.G.; Dolic, M.B.; Gernjak, W.; Heath, E.; Ivancev-Tumbas, I.; Karaolia, P.; Ribeiro, A.R.L.; et al. Consolidated vs new advanced treatment methods for the removal of contaminants of emerging concern from urban wastewater. Sci. Total Environ. 2019, 655, 986-1008. [CrossRef]

46. El Assal, Z.; Ojala, S.; Zbair, M.; Echchtouki, H.; Nevanpera, T.; Pitkaaho, S.; Pirault-Roy, L.; Bensitel, M.; Brahmi, R.; Keiski, R.L. Catalytic abatement of dichloromethane over transition metal oxide catalysts: Thermodynamic modelling and experimental studies. J. Clean. Prod. 2019, 228, 814-823. [CrossRef]

47. Da Silva, F.L.; Laitinen, T.; Pirila, M.; Keiski, R.L.; Ojala, S. Photocatalytic Degradation of Perfluorooctanoic Acid (PFOA) From Wastewaters by $\mathrm{TiO}_{2}, \mathrm{In}_{2} \mathrm{O}_{3}$ and $\mathrm{Ga}_{2} \mathrm{O}_{3}$ Catalysts. Top. Catal. 2017, 60, 1345-1358. [CrossRef]

48. Sassi, H.; Lafaye, G.; Ben Amor, H.; Gannouni, A.; Jeday, M.R.; Barbier, J. Wastewater treatment by catalytic wet air oxidation process over Al-Fe pillared clays synthesized using microwave irradiation. Front. Environ. Sci. Eng. 2018, 12, 2. [CrossRef]

49. Espindola, J.C.; Cristovao, R.O.; Araujo, S.R.F.; Neuparth, T.; Santos, M.M.; Montes, R.; Quintana, J.B.; Rodil, R.; Boaventura, R.A.R.; Vilar, V.J.P. An innovative photoreactor, FluHelik, to promote $\mathrm{UVC} / \mathrm{H}_{2} \mathrm{O}_{2}$ photochemical reactions: Tertiary treatment of an urban wastewater. Sci. Total Environ. 2019, 667, 197-207. [CrossRef] [PubMed]

50. Di Cesare, A.; De Carluccio, M.; Eckert, E.M.; Fontaneto, D.; Fiorentino, A.; Corno, G.; Prete, P.; Cucciniello, R.; Proto, A.; Rizzo, L. Combination of flow cytometry and molecular analysis to monitor the effect of $U V C / \mathrm{H}_{2} \mathrm{O}_{2}$ vs $\mathrm{UVC} / \mathrm{H}_{2} \mathrm{O}_{2} / \mathrm{Cu}$-IDS processes on pathogens and antibiotic resistant genes in secondary wastewater effluents. Water Res. 2020, 184, 116194. [CrossRef] [PubMed]

51. Diez, A.M.; Moreira, F.C.; Marinho, B.A.; Espindola, J.C.A.; Paulista, L.O.; Sanroman, M.A.; Pazos, M.; Boaventura, R.A.R.; Vilar, V.J.P. A step forward in heterogeneous photocatalysis: Process intensification by using a static mixer as catalyst support. Chem. Eng. J. 2018, 343, 597-606. [CrossRef]

52. Stathoulopoulos, A.; Mantzavinos, D.; Frontistis, Z. Coupling Persulfate-Based AOPs: A Novel Approach for Piroxicam Degradation in Aqueous Matrices. Water 2020, 12, 1530. [CrossRef]

53. Steinle-Darling, E.; Zedda, M.; Plumlee, M.H.; Ridgway, H.F.; Reinhard, M. Evaluating the impacts of membrane type, coating, fouling, chemical properties and water chemistry on reverse osmosis rejection of seven nitrosoalklyamines, including NDMA. Water Res. 2007, 41, 3959-3967. [CrossRef]

54. Yoon, Y.; Westerhoff, P.; Snyder, S.A.; Wert, E.C. Nanofiltration and ultrafiltration of endocrine disrupting compounds, pharmaceuticals and personal care products. J. Membr. Sci. 2006, 270, 88-100. [CrossRef]

55. Nghiem, L.D.; Schafer, A.I.; Elimelech, M. Pharmaceutical retention mechanisms by nanofiltration membranes. Environ. Sci. Technol. 2005, 39, 7698-7705. [CrossRef]

56. Singh, R.; Hankins, N. Emerging Membrane Technology for Sustainable Water Treatment; Elsevier: Amsterdam, The Netherlands, 2016.

57. Xie, Z.; Li, N.; Wang, Q.; Bolto, B. Desalination by pervaporation. In Emerging Technologies for Sustainable Desalination Handbook; Elsevier: Amsterdam, The Netherlands, 2018; pp. 205-226.

58. Eyvaz, M.; Yüksel, E. Desalination and Water Treatment; IntechOpen: London, UK, 2018.

59. Acero, J.L.; Benitez, F.J.; Teva, F.; Leal, A.I. Retention of emerging micropollutants from UP water and a municipal secondary effluent by ultrafiltration and nanofiltration. Chem. Eng. J. 2010, 163, 264-272. [CrossRef] 
60. Urtiaga, A.M.; Pérez, G.; Ibáñez, R.; Ortiz, I. Removal of pharmaceuticals from a WWTP secondary effluent by ultrafiltration/reverse osmosis followed by electrochemical oxidation of the RO concentrate. Desalination 2013, 331, 26-34. [CrossRef]

61. Radjenović, J.; Petrović, M.; Ventura, F.; Barceló, D. Rejection of pharmaceuticals in nanofiltration and reverse osmosis membrane drinking water treatment. Water Res. 2008, 42, 3601-3610. [CrossRef]

62. D'Haese, A.; Le-Clech, P.; Van Nevel, S.; Verbeken, K.; Cornelissen, E.R.; Khan, S.J.; Verliefde, A.R.D. Trace organic solutes in closed-loop forward osmosis applications: Influence of membrane fouling and modeling of solute build-up. Water Res. 2013, 47, 5232-5244. [CrossRef] [PubMed]

63. Wang, L.; Albasi, C.; Faucet-Marquis, V.; Pfohl-Leszkowicz, A.; Dorandeu, C.; Marion, B.; Causserand, C. Cyclophosphamide removal from water by nanofiltration and reverse osmosis membrane. Water Res. 2009, 43, 4115-4122. [CrossRef] [PubMed]

64. Silvestre, W.P.; Baldasso, C.; Tessaro, I.C. Potential of chitosan-based membranes for the separation of essential oil components by target-organophilic pervaporation. Carbohydr. Polym. 2020, 247, 116676. [CrossRef] [PubMed]

65. Zeng, H.Z.; Liu, S.J.; Wang, J.; Li, Y.B.; Zhu, L.; Xu, M.; Wang, C.W. Hydrophilic SPEEK/PES composite membrane for pervaporation desalination. Sep. Purif. Technol. 2020, 250, 117265. [CrossRef]

66. Cheng, X.X.; Pan, F.S.; Wang, M.R.; Li, W.D.; Song, Y.M.; Liu, G.H.; Yang, H.; Gao, B.X.; Wu, H.; Jiang, Z.Y. Hybrid membranes for pervaporation separations. J. Membr. Sci. 2017, 541, 329-346. [CrossRef]

67. Liu, G.P.; Wei, W.; Wu, H.; Dong, X.L.; Jiang, M.; Jin, W.Q. Pervaporation performance of PDMS/ceramic composite membrane in acetone butanol ethanol (ABE) fermentation-PV coupled process. J. Membr. Sci. 2011, 373, 121-129. [CrossRef]

68. Wu, Y.; Fu, X.; Tian, G.; Xuehong, G.; Liu, Z. Pervaporation of phenol wastewater with PEBA-PU blend membrane. Desalin. Water Treat. 2018, 102, 101-109. [CrossRef]

69. Halakoo, E.; Feng, X. Layer-by-layer assembly of polyethyleneimine/graphene oxide membranes for desalination of high-salinity water via pervaporation. Sep. Purif. Technol. 2020, 234, 116077. [CrossRef]

70. Crespo, J.G.; Brazinha, C. 1-Fundamentals of pervaporation. In Pervaporation, Vapour Permeation and Membrane Distillation; Basile, A., Figoli, A., Khayet, M., Eds.; Woodhead Publishing: Oxford, UK, 2015; pp. 3-17. [CrossRef]

71. Van der Bruggen, B.; Luis, P. Chapter Four-Pervaporation. In Progress in Filtration and Separation; Tarleton, S., Ed.; Academic Press: Oxford, UK, 2015; pp. 101-154. [CrossRef]

72. Dhangar, K.; Kumar, M. Tricks and tracks in removal of emerging contaminants from the wastewater through hybrid treatment systems: A review. Sci. Total Environ. 2020, 738, 140320. [CrossRef] [PubMed]

73. Van der Bruggen, B.; Schaep, J.; Wilms, D.; Vandecasteele, C. Influence of molecular size, polarity and charge on the retention of organic molecules by nanofiltration. J. Membr. Sci. 1999, 156, 29-41. [CrossRef]

74. Yangali-Quintanilla, V.; Maeng, S.K.; Fujioka, T.; Kennedy, M.; Li, Z.Y.; Amy, G. Nanofiltration vs. reverse osmosis for the removal of emerging organic contaminants in water reuse. Desalin. Water Treat. 2011, 34, 50-56. [CrossRef]

75. Nghiem, L.D.; Schafer, A.I.; Elimelech, M. Role of electrostatic interactions in the retention of pharmaceutically active contaminants by a loose nanofiltration membrane. J. Membr. Sci. 2006, 286, 52-59. [CrossRef]

76. Childress, A.E.; Elimelech, M. Relating nanofiltration membrane performance to membrane charge (electrokinetic) characteristics. Environ. Sci. Technol. 2000, 34, 3710-3716. [CrossRef]

77. Yangali-Quintanilla, V.; Maeng, S.K.; Fujioka, T.; Kennedy, M.; Amy, G. Proposing nanofiltration as acceptable barrier for organic contaminants in water reuse. J. Membr. Sci. 2010, 362, 334-345. [CrossRef]

78. Coday, B.D.; Yaffe, B.G.M.; Xu, P.; Cath, T.Y. Rejection of Trace Organic Compounds by Forward Osmosis Membranes: A Literature Review. Environ. Sci. Technol. 2014, 48, 3612-3624. [CrossRef] [PubMed]

79. Lee, Y.E.; Jang, A. Effect of forward osmosis (membrane) support layer fouling by organic matter in synthetic seawater solution. Desalin. Water Treat. 2016, 57, 24595-24605. [CrossRef]

80. Linares, R.V.; Yangali-Quintanilla, V.; Li, Z.Y.; Amy, G. Rejection of micropollutants by clean and fouled forward osmosis membrane. Water Res. 2011, 45, 6737-6744. [CrossRef]

81. Agenson, K.O.; Urase, T. Change in membrane performance due to organic fouling in nanofiltration (NF)/reverse osmosis (RO) applications. Sep. Purif. Technol. 2007, 55, 147-156. [CrossRef]

82. Joo, S.H.; Tansel, B. Novel technologies for reverse osmosis concentrate treatment: A review. J. Environ. Manag. 2015, 150, 322-335. [CrossRef] 
83. Kaminski, W.; Marszalek, J.; Tomczak, E. Water desalination by pervaporation-Comparison of energy consumption. Desalination 2018, 433, 89-93. [CrossRef]

84. Araki, S.; Gondo, D.; Yamamoto, H. Pervaporation properties and a semi-empirical model for removal of VOCs from water using a propyl functionalized silica membrane. Desalin. Water Treat. 2019, 143, 17-23. [CrossRef]

85. Higuchi, A.; Yoon, B.O.; Asano, T.; Nakaegawa, K.; Miki, S.; Hara, M.; He, Z.J.; Pinnau, I. Separation of endocrine disruptors from aqueous solutions by pervaporation. J. Membr. Sci. 2002, 198, 311-320. [CrossRef]

86. Higuchi, A.; Yoon, B.O.; Kaneko, T.; Ham, M.; Maekawa, M.; Nohmi, T. Separation of endocrine disruptors from aqueous solutions by pervaporation: Dioctylphthalate and butylated hydroxytoluene in mineral water. J. Appl. Polym. Sci. 2004, 94, 1737-1742. [CrossRef]

87. Wang, Q.; Li, N.; Bolto, B.; Hoang, M.; Xie, Z. Desalination by pervaporation: A review. Desalination 2016, 387, 46-60. [CrossRef]

88. Egea-Corbacho, A.; Gutierrez, S.; Quiroga, J.M. Removal of emerging contaminants from wastewater through pilot plants using intermittent sand/coke filters for its subsequent reuse. Sci. Total Environ. 2019, 646, 1232-1240. [CrossRef] [PubMed]

89. Yan, T.; Ye, Y.Y.; Ma, H.M.; Zhang, Y.; Guo, W.S.; Du, B.; Wei, Q.; Wei, D.; Ngo, H.H. A critical review on membrane hybrid system for nutrient recovery from wastewater. Chem. Eng. J. 2018, 348, 143-156. [CrossRef]

90. Dharupaneedi, S.P.; Nataraj, S.K.; Nadagouda, M.; Reddy, K.R.; Shukla, S.S.; Aminabhavi, T.M. Membrane-based separation of potential emerging pollutants. Sep. Purif. Technol. 2019, 210, 850-866. [CrossRef]

91. Taheran, M.; Brar, S.K.; Verma, M.; Surampalli, R.Y.; Zhang, T.C.; Valero, J.R. Membrane processes for removal of pharmaceutically active compounds (PhACs) from water and wastewaters. Sci. Total Environ. 2016, 547, 60-77. [CrossRef]

92. Bellona, C.; Drewes, J.E. The role of membrane surface charge and solute physico-chemical properties in the rejection of organic acids by NF membranes. J. Membr. Sci. 2005, 249, 227-234. [CrossRef]

93. Xu, P.; Drewes, J.E.; Kim, T.U.; Bellona, C.; Amy, G. Effect of membrane fouling on transport of organic contaminants in NF/RO membrane applications. J. Membr. Sci. 2006, 279, 165-175. [CrossRef]

94. Nghiem, L.D.; Coleman, P.J.; Espendiller, C. Mechanisms underlying the effects of membrane fouling on the nanofiltration of trace organic contaminants. Desalination 2010, 250, 682-687. [CrossRef]

95. Bellona, C.; Marts, M.; Drewes, J.E. The effect of organic membrane fouling on the properties and rejection characteristics of nanofiltration membranes. Sep. Purif. Technol. 2010, 74, 44-54. [CrossRef]

96. Nghiem, L.D.; Schafer, A.I.; Elimelech, M. Removal of natural hormones by nanofiltration membranes: Measurement, modeling, and mechanisms. Environ. Sci. Technol. 2004, 38, 1888-1896. [CrossRef] [PubMed]

97. Sgroi, M.; Anumol, T.; Roccaro, P.; Vagliasindi, F.G.A.; Snyder, S.A. Modeling emerging contaminants breakthrough in packed bed adsorption columns by UV absorbance and fluorescing components of dissolved organic matter. Water Res. 2018, 145, 667-677. [CrossRef]

98. Vergili, I. Application of nanofiltration for the removal of carbamazepine, diclofenac and ibuprofen from drinking water sources. J. Environ. Manag. 2013, 127, 177-187. [CrossRef]

99. Romanos, G.E.; Athanasekou, C.P.; Likodimos, V.; Aloupogiannis, P.; Falaras, P. Hybrid Ultrafiltration/Photocatalytic Membranes for Efficient Water Treatment. Ind. Eng. Chem. Res. 2013, 52, 13938-13947. [CrossRef]

100. Papageorgiou, S.K.; Katsaros, F.K.; Favvas, E.P.; Romanos, G.E.; Athanasekou, C.P.; Beltsios, K.G.; Tzialla, O.I.; Falaras, P. Alginate fibers as photocatalyst immobilizing agents applied in hybrid photocatalytic/ultrafiltration water treatment processes. Water Res. 2012, 46, 1858-1872. [CrossRef]

101. Athanasekou, C.P.; Romanos, G.E.; Katsaros, F.K.; Kordatos, K.; Likodimos, V.; Falaras, P. Very efficient composite titania membranes in hybrid ultrafiltration/photocatalysis water treatment processes. J. Membr. Sci. 2012, 392, 192-203. [CrossRef]

102. Romanos, G.E.; Athanasekou, C.P.; Katsaros, F.K.; Kanellopoulos, N.K.; Dionysiou, D.D.; Likodimos, V.; Falaras, P. Double-side active $\mathrm{TiO}_{2}$-modified nanofiltration membranes in continuous flow photocatalytic reactors for effective water purification. J. Hazard. Mater. 2012, 211, 304-316. [CrossRef]

103. Lin, J.C.T.; Lee, D.J.; Huang, C.P. Membrane Fouling Mitigation: Membrane Cleaning. Sep. Sci. Technol. 2010, 45, 858-872. [CrossRef] 
104. Warsinger, D.M.; Chakraborty, S.; Tow, E.W.; Plumlee, M.H.; Bellona, C.; Loutatidou, S.; Karimi, L.; Mikelonis, A.M.; Achilli, A.; Ghassemi, A.; et al. A review of polymeric membranes and processes for potable water reuse. Prog. Polym. Sci. 2016, 81, 209-237. [CrossRef] [PubMed]

105. Pesqueira, J.F.J.R.; Pereira, M.F.R.; Silva, A.M.T. Environmental impact assessment of advanced urban wastewater treatment technologies for the removal of priority substances and contaminants of emerging concern: A review. J. Clean. Prod. 2020, 261, 1210178. [CrossRef]

106. Tarpani, R.R.Z.; Azapagic, A. Life cycle environmental impacts of advanced wastewater treatment techniques for removal of pharmaceuticals and personal care products (PPCPs). J. Environ. Manag. 2018, 215, 258-272. [CrossRef] [PubMed]

107. Rahman, S.M.; Eckelman, M.J.; Onnis-Hayden, A.; Gu, A.Z. Comparative Life Cycle Assessment of Advanced Wastewater Treatment Processes for Removal of Chemicals of Emerging Concern. Environ. Sci. Technol. 2018, 52, 11346-11358. [CrossRef]

108. Li, Y.; Zhang, S.X.; Zhang, W.L.; Xiong, W.; Ye, Q.L.; Hou, X.; Wang, C.; Wang, P.F. Life cycle assessment of advanced wastewater treatment processes: Involving 126 pharmaceuticals and personal care products in life cycle inventory. J. Environ. Manag. 2019, 238, 442-450. [CrossRef]

109. Castro-Munoz, R. Pervaporation: The emerging technique for extracting aroma compounds from food systems. J. Food Eng. 2019, 253, 27-39. [CrossRef]

110. Silvestre, W.P.; Livinalli, N.F.; Baldasso, C.; Tessaro, I.C. Pervaporation in the separation of essential oil components: A review. Trends Food Sci. Technol. 2019, 93, 42-52. [CrossRef]

111. Jyoti, G.; Keshav, A.; Anandkumar, J. Review on Pervaporation: Theory, Membrane Performance, and Application to Intensification of Esterification Reaction. J. Eng. 2015, 2015, 927068. [CrossRef]

112. Meng, D.P.; Dai, Y.; Xu, Y.; Wu, Y.M.; Cui, P.Z.; Zhu, Z.Y.; Ma, Y.X.; Wang, Y.L. Energy, economic and environmental evaluations for the separation of ethyl acetate/ethanol/water mixture via distillation and pervaporation unit. Process Saf. Environ. Prot. 2020, 140, 14-25. [CrossRef]

113. Mei, X.; Ding, Y.; Li, P.P.; Xu, L.J.; Wang, Y.; Guo, Z.W.; Shen, W.T.; Yang, Y.; Wang, Y.H.; Xiao, Y.Y.; et al. A novel system for zero-discharge treatment of high-salinity acetonitrile-containing wastewater: Combination of pervaporation with a membrane-aerated bioreactor. Chem. Eng. J. 2020, 384, 123338. [CrossRef]

114. Wang, Y.; Mei, X.; Ma, T.F.; Xue, C.J.; Wu, M.D.; Ji, M.; Li, Y.G. Green recovery of hazardous acetonitrile from high-salt chemical wastewater by pervaporation. J. Clean. Prod. 2018, 197, 742-749. [CrossRef]

115. Tgarguifa, A.; Abderafi, S.; Bounahmidi, T. Energy efficiency improvement of a bioethanol distillery, by replacing a rectifying column with a pervaporation unit. Renew. Energy 2018, 122, 239-250. [CrossRef]

116. Lipski, C.; Cote, P. The Use of Pervaporation for the Removal of Organic Contaminants from Water. Environ. Prog. 1990, 9, 254-261. [CrossRef]

117. Feng, X.S.; Huang, R.Y.M. Liquid separation by membrane pervaporation: A review. Ind. Eng. Chem. Res. 1997, 36, 1048-1066. [CrossRef]

118. Baker, R.W.; Wijmans, J.G.; Huang, Y. Permeability, Permeance and Selectivity: A preferred Way of Reporting Pervaporation Performance Data. J. Membr. Sci. 2010, 348, 346-352. [CrossRef]

119. Gani, K.M.; Kazmi, A.A. Comparative assessment of phthalate removal and risk in biological wastewater treatment systems of developing countries and small communities. Sci. Total Environ. 2016, 569, 661-671. [CrossRef] [PubMed]

120. Jobling, S.; Reynolds, T.; White, R.; Parker, M.G.; Sumpter, J.P. A Variety of Environmentally Persistent Chemicals, Including Some Phthalate Plasticizers, Are Weakly Estrogenic. Environ. Health Perspect. 1995, 103, 582-587. [CrossRef]

121. Yoon, B.O.; Koyanagi, S.; Asano, T.; Hara, M.; Higuchi, A. Removal of endocrine disruptors by selective sorption method using polydimethylsiloxane membranes. J. Membr. Sci. 2003, 213, 137-144. [CrossRef]

122. Waters, L.J.; Bhuiyan, A.K.M.M.H. Ionisation effects on the permeation of pharmaceutical compounds through silicone membrane. Colloids Surf. B Biointerfaces 2016, 141, 553-557. [CrossRef]

123. Bhuiyan, A.K.M.M.H.; Waters, L.J. Permeation of pharmaceutical compounds through silicone membrane in the presence of surfactants. Colloid Surf. A 2017, 516, 121-128. [CrossRef]

124. Sauve, S.; Desrosiers, M. A review of what is an emerging contaminant. Chem. Cent. J. 2014, 8, 15. [CrossRef] [PubMed] 
125. Garrett, E.R.; Chemburk, P.B. Evaluation Control and Prediction of Drug Diffusion through Polymeric Membranes I. Methods Reproducibility of Steady-State Diffusion Studies. J. Pharm. Sci. 1968, 57, 944-948. [CrossRef] [PubMed]

126. Garrett, E.R.; Chemburk, P.B. Evaluation Control and Prediction of Drug Diffusion through Polymeric Membranes II. Diffusion of Aminophenones through Silastic Membranes-A Test of Ph-Partition Hypothesis. J. Pharm. Sci. 1968, 57, 949-959. [CrossRef] [PubMed]

127. Garrett, E.R.; Chemburkar, P.B. Evaluation Control and Prediction of Drug Diffusion through Polymeric Membranes III. Diffusion of Barbiturates Phenylalkylamines Dextromethorphan Progesterone and Other Drugs. J. Pharm. Sci. 1968, 57, 1401-1409. [CrossRef]

128. Brouwer, E.R.; Lingeman, H.; Brinkman, U.A.T. Use of membrane extraction disks for on-line trace enrichment of organic compounds from aqueous samples. Chromatographia 1990, 29, 415-418. [CrossRef]

129. Poliwoda, A.; Krzyżak, M.; Wieczorek, P.P. Supported liquid membrane extraction with single hollow fiber for the analysis of fluoroquinolones from environmental surface water samples. J. Chromatogr. A 2010, 1217, 3590-3597. [CrossRef]

130. Megersa, N.; Chimuka, L.; Solomon, T.; Jönsson, J.Å. Automated liquid membrane extraction and trace enrichment of triazine herbicides and their metabolites in environmental and biological samples. J. Sep. Sci. 2001, 24, 567-576. [CrossRef]

131. Guo, X.; Mitra, S. Development of pulse introduction membrane extraction for analysis of volatile organic compounds in individual aqueous samples, and for continuous on-line monitoring. J. Chromatogr. A 1998, 826, 39-47. [CrossRef]

132. Prieto, A.; Telleria, O.; Etxebarria, N.; Fernández, L.A.; Usobiaga, A.; Zuloaga, O. Simultaneous preconcentration of a wide variety of organic pollutants in water samples: Comparison of stir bar sorptive extraction and membrane-assisted solvent extraction. J. Chromatogr. A 2008, 1214, 1-10. [CrossRef]

133. Ray, S.K.; Sawant, S.B.; Joshi, J.B.; Pangarkar, V.G. Perstraction of Phenolic Compounds from Aqueous Solution Using a Nonporous Membrane. Sep. Sci. Technol. 1997, 32, 2669-2683. [CrossRef]

134. Rodil, R.; Schrader, S.; Moeder, M. Non-porous membrane-assisted liquid-liquid extraction of UV filter compounds from water samples. J. Chromatogr. A 2009, 1216, 4887-4894. [CrossRef] [PubMed]

135. Rodil, R.; Schrader, S.; Moeder, M. Pressurised membrane-assisted liquid extraction of UV filters from sludge. J. Chromatogr. A 2009, 1216, 8851-8858. [CrossRef] [PubMed]

136. Villaverde-de-Sáa, E.; González-Mariño, I.; Quintana, J.B.; Rodil, R.; Rodríguez, I.; Cela, R. In-sample acetylation-non-porous membrane-assisted liquid-liquid extraction for the determination of parabens and triclosan in water samples. Anal. Bioanal. Chem. 2010, 397, 2559-2568. [CrossRef] [PubMed]

137. Yamini, Y.; Reimann, C.T.; Vatanara, A.; Jönsson, J.Å. Extraction and preconcentration of salbutamol and terbutaline from aqueous samples using hollow fiber supported liquid membrane containing anionic carrier. J. Chromatogr. A 2006, 1124, 57-67. [CrossRef] [PubMed]

138. Einsle, T.; Paschke, H.; Bruns, K.; Schrader, S.; Popp, P.; Moeder, M. Membrane-assisted liquid-liquid extraction coupled with gas chromatography-mass spectrometry for determination of selected polycyclic musk compounds and drugs in water samples. J. Chromatogr. A 2006, 1124, 196-204. [CrossRef] [PubMed]

139. Hylton, K.; Mitra, S. Automated, on-line membrane extraction. J. Chromatogr. A 2007, 1152, $199-214$. [CrossRef]

140. Jönsson, J.Å.; Mathiasson, L. Membrane-based techniques for sample enrichment. J. Chromatogr. A 2000, 902, 205-225. [CrossRef]

Publisher's Note: MDPI stays neutral with regard to jurisdictional claims in published maps and institutional affiliations.

(C) 2020 by the authors. Licensee MDPI, Basel, Switzerland. This article is an open access article distributed under the terms and conditions of the Creative Commons Attribution (CC BY) license (http://creativecommons.org/licenses/by/4.0/). 